\title{
KARAKTERISTIK MI KERING DENGAN SUBSTITUSI TEPUNG GEMBILI DAN PENAMBAHAN PLASTIZISER GMS (GLISEROL MONO STEARAT)
}

\author{
Sri Winarti*, Enny Karti Basuki Susiloningsih, Ferry Yusuf Zaenal Fasroh \\ Teknologi Hasil Pangan, UPN Surabaya \\ Email: swin_tpupn@yahoo.com
}

\begin{abstract}
ABSTRAK
Mi saat ini merupakan salah satu makanan yang sangat digemari semua masyarakat, hal ini didukung dengan kecenderungan dan pola hidup masyarakat modern yang lebih menginginkan makanan siap saji. Kebutuhan terigu yang merupakan bahan dasar pembuatan Mi perlu diimbangi dengan upaya substitusi dengan bahan baku local, salah satu alternatif menggunakan tepung umbi gembili (Dioscorea esculenta L.). Meskipun telah dapat dikembangkan menjadi tepung, kelemahan dari sifat fungsional tepung umbi gembili ialah tidak adanya kandungan gluten pada tepung gembili yang mengakibatkan adonan Mi kurang elastis. Salah satu upaya untuk memperbaiki kelemahan tersebut adalah dengan penambahan plastisizer yaitu gliserol monostearat untuk memperbaiki karakteristik Mi kering. Penelitian ini bertujuan mempelajari pengaruh substitusi tepung gembili dan penambahan gliserol monostearat terhadap kualitas fisikokimia dan organoleptik Mi, sehingga dihasilkan Mi dengan kualitas baik dan disukai konsumen. Rancangan penelitian yang digunakan adalah Rancangan Acak Lengkap (RAL) yang terdiri dari 12 perlakuan dan tiga kali ulangan dengan perlakuan substitusi tepung gembili $(0 \% ; 15 \% ; 30 \%$; dan $45 \%)$ dan penambahan GMS $(1 \% ; 2 \% ; 3 \%)$. Data dianalisa menggunakan metode two-way ANOVA pada tingkat kepercayaan 95\%, Jika ada perbedaan antar perlakuan dilanjutkan dengan Uji Duncan $\alpha=5 \%$, dan untuk analisa uji organoleptik menggunakan metode hedonik scale scoring dengan perhitungan data menggunakan metode friedman. Hasil penelitian menunjukan Mi kering tepung gembili dengan perlakuan substitusi tepung gembili $15 \%$ dan penambahan gliserol monostearat 3\% merupakan perlakuan terbaik dengan nilai kadar air 8,84\%, kadar abu 1,65\%, kadar protein 7,50\%, kadar pati 55,99\%, daya rehidrasi $41,93 \%$, elastisitas $25,69 \%$, cooking loss $7,94 \%$, serta jumlah ranking warna 132,00, aroma 114,50, dan tekstur 183,00.
\end{abstract}

Kata kunci : Mi kering, tepung gembili, gliserol mono stearat

\section{PENDAHULUAN}

Mi merupakan salah satu masakan yang sangat populer di Asia, salah satunya di Indonesia. Tetapi bahan baku Mi yaitu tepung terigu masih $100 \%$ diperoleh dari impor. Indonesia tidak bisa memproduksi sendiri gandum sebagai tumbuhan penghasil tepung terigu, karena iklim yang kurang cocok.

Upaya untuk mengurangi ketergantungan tepung terigu, dibutuhkan pencampuran sebagian ataupun keseluruhan bahan dengan tepung non terigu sebagai bahan pembuatan makanan. Salah satu pilihan pengganti tepung terigu pada pembuatan $\mathrm{Mi}$ kering, yaitu dengan mengganti sebagian atau keseluruhan bahan dengan tepung gembili.
Gembili berpotensi sebagai sumber karbohidrat, protein, rendah lemak, kalsium, fosfor, potassium, zat besi, serat yang cukup dikenal, vitaMin B6 dan C (Tia, 2011). Selain itu gembili juga merupakan tanaman lokal yang mengandung inulin, kandungan inulin pada gembili merupakan yang tertinggi yaitu sebesar 14,77\% (Winarti dkk, 2011). Sifat fungsional inulin ialah sebagai serat makanan dapat larut (soluble dietary fiber) sangat bermanfaat bagi pencernaan dan kesehatan tubuh (Sardesai, 2003). Inulin ialah gugus polimer dari unit-unit fruktosa dengan gugus terminal glukosa. Unit-unit fruktosa dalam inulin dihubungkan oleh ikatan $B(2-1)$ glikosidik, sehingga tidak dapat dicerna oleh enzim-enzim dalam sistem pencernaan 
mamalia dan mencapai usus besar tanpa mengalami perubahan struktur, oleh karena itu inulin dapat berfungsi sebagai prebiotik (Robertfroid, 2005).

Dalam pembuatan $\mathrm{Mi}$, komponen utama dari bahan dasar pembuatan Mi adalah kandungan protein tepung terigu yaitu gliadin dan glutenin yang berfungsi membentuk struktur Mi. Gliadin dan glutenin adalah protein dari tepung terigu dan merupakan massa kenyal yang lengket dan tersusun atas gluten yang bertanggung jawab terhadap elastisitas adonan (De Man, 1997).

Karakteristik penting dari tepung yang mempengaruhi tekstur $\mathrm{Mi}$ adalah kadar protein, proporsi relatif antara protein dan pati, serta sifat fungsional protein dan pati dalam terigu. Pada Mi yang komponen bahan dasar serta pengolahannya sederhana, karakteristik fisiko kimia pati dan protein kemungkinan memainkan peran yang lebih besar dalam pengolahan dan mutu produk, dibandingkan dengan produk-produk bakery, seperti roti, cake, kue kering dan pastry (Hou, 2010).

Penambahan gembili pada pembuatan Mi menyebabkan kekurangtegaran adonan Mi sehingga Mi susah untuk dibentuk. Oleh karena itu, ditambahkan GMS (gliserol mono stearat). Penambahan GMS dapat menyebabkan tekstur yang kompak dan kenyal pada produk yang dihasilkan. semakin tinggi penambahan gliserol mono stearat yang ditambahkan maka lapisan film yang terbentuk semakin kokoh dan tekstur yang dihasilkan juga semakin kokoh. Hal ini menjadikan penambahan gliserol mono stearat meningkatkan daya renggang atau elastisitas pada produk yang dihasilkan (Kuswardani dkk., 2008).

Permasalahan yang timbul dalam pembuatan Mi dari bahan baku tepung komposit adalah produk yang dihasilkan memiliki kadar protein, daya putus $\mathrm{Mi}$, dan tingkat kekenyalan Mi yang menurun. Hal ini sesuai dengan penelitian (Halwan dan Nisa, 2015) menyatakan bahwa semakin banyak proporsi tepung gembili menyebabkan kadar protein Mi semakin menurun karena nilai protein gembili pada penelitian ini sangat rendah sebesar 2,94\%. Penelitian tersebut menyatakan nilai daya putus $\mathrm{Mi}$ cenderung menurun seiring dengan meningkatnya proporsi gembili, yang dikarenakan rendahnya nilai protein sehingga berpengaruh pada kemampuan mengikat bahan. Protein berperan sebagai bahan pengikat dalam adonan yang akan menentukan tekstur kekenyalan (Astawan, 2008).

Penelitian tentang pembuatan Mi jagung (non terigu) dengan penambahan GMS telah dilakukan oleh Subarna dkk. (2012). Pada penelitian tersebut dengan variasi penambahan GMS dengan 4 tingkat konsentrasi. Dari 4 konsentrasi penambahan GMS didapat bahwa penambahan GMS 1\% (dari berat tepung) ternyata mampu memperbaiki karakteristik Mi kering jagung yang telah di rehidrasi. Bahwa Mi kering jagung yang telah direhidrasi memiliki elongasi, ketegaran, kekenyalan, dan penampakan umum yang disukai panelis.

Berdasarkan uraian diatas, maka dalam penelitian ini dilakukan formulasi pembuatan Mi kering dengan substitusi tepung gembili dan penambahan GMS (gliserol monostearat).

Tujuan Penelitian adalah mempelajari pengaruh substitusi tepung gembili dan penambahan gliserol monostearat (GMS) terhadap kualitas fisikokimia dan organoleptik Mi kering; dan mencari kombinasi terbaik antara substitusi tepung gembili dan penambahan gliserol monostearat (GMS) sehingga dihasilkan Mi kering dengan kualitas baik dan disukai konsumen.

\section{METODE}

\section{Bahan dan Alat}

Bahan-bahan yang digunakan untuk pembuatan Mi kering yaitu tepung terigu protein tinggi (merek cakra), garam, telur ayam, minyak goreng yang diperoleh dari Pasar Larangan Sidoarjo, tepung gembili yang diperoleh dari Nganjuk (usia matang). Pembelian gliserol monosterat dibeli dari Toko Kimia di Surabaya. Bahan untuk analisa kimia adalah $\mathrm{NaOH} 1 \mathrm{~N}$, aquades, eter, $\mathrm{H}_{2} \mathrm{SO}_{4}$, teblet kjeldahl, asam borat, dan alkohol $95 \%$ yang diperoleh dari toko bahan kimia.

Alat-alat yang digunakan dalam penelitian ini adalah alat pengolahan dalam pembuatan tepung gembili dan pembuatan $\mathrm{Mi}$ kering yang meliputi mesin penyawut, cabinet drier, diskmill, ayakan, pencetak Mi dan alatalat penunjang. Peralatan untuk analisa 
meliputi timbangan analitik, waterbath, desikator, oven, dan Tensile Strenght.

\section{Prosedur Penelitian}

\section{1) Pembuatan Tepung Gembili}

a) Memilih umbi gembili yang baik dan tidak cacat/luka.

b) Mengupas kulit umbi gembili.

c) Mencuci umbi gembili yang sudah dikupas dengan air mengalir.

d) Memperkecil ukuran umbi gembili dengan cara disawut.

e) Mengeringkan tepung gembili dengan cabinet dryer selama 8-12 jam atau sampai kering pada suhu $60^{\circ} \mathrm{C}$.

f) Menggiling umbi gembili tersebut menggunakan diskmill sampai halus dan kemudian mengayak umbi gembili yang sudah halus tersebut menggunakan ayakan dengan ukuran 80 mesh.

g) tepung umbi gembili yang diperoleh segera dikemas menggunakan plastik kedap udara.

\section{2) Proses Pembuatan Mi kering}

Pembuatan Mi kering dengan proporsi tepung terigu:tepung gembili (100\%:0\%; 85\%:15\%; 70\%:30\% dan 55\%:45\%) dan penambahan gliseril monosterat $(1 \%, 2 \%$, $3 \%$ ). Langkah kerja pembuatan Mi kering dapat dilihat sebagai berikut :

a. Penimbangan bahan-bahan sesuai ketentuan.

b. Tahap pencampuran ini dilakukan terlebih dahulu untuk bahan-bahan kering sambil ditambahkan air, telur dan minyak sambil diaduk selama 1525 menit hingga adonan homogen.

c. Adonan dibuat lembaran dengan tebal akhir 1,2-2 mm. Selanjutnya lembaran dipotong dan dibentuk Mi.

d. Pengukusan menggunakan panci dengan suhu $100^{\circ}-105^{\circ} \mathrm{C}$ selama $15-20$ menit, dan dikeringkan selama 3 jam dengan suhu $60^{\circ} \mathrm{C}$, lalu dilakukan pendinginan cepat hingga suhu $40^{\circ} \mathrm{C}$.

\section{3) Parameter yang diamati}

Parameter yang diamati pada Mi meliputi: kadar air metode oven (AOAC, 2005), kadar protein (AOAC, 2005), kadar pati (AOAC, 2005); karakteristik fisik (Cooking loss, Elastisitas dan daya rehidrasi), uji sensoris terhadap Mi yang telah dikukus meliputi warna, aroma, dan tekstur. Data-data yang diperoleh dianalisis menggunakan ANOVA, uji lanjut menggunakan Uji Duncan $(\alpha=5 \%)$.

\section{HASIL DAN PEMBAHASAN}

\section{Kadar Air Mi Kering}

Berdasarkan analisis ragam menunjukkan bahwa perlakuan substitusi tepung gembili dan penambahan gliserol monostearate terdapat interaksi yang nyata terhadap kadar air Mi kering, dan masingmasing perlakuan berpengaruh nyata $(\mathrm{p}<0,05)$ terhadap kadar air Mi kering. Nilai rata - rata kadar air Mi kering tiap perlakuan dapat dilihat pada Tabel 1.

Dari Tabel 1. menunjukkan bahwa dengan semakin rendah proporsi tepung gembili atau semakin tinggi penambahan gliserol monostearat menyebabkan kadar air Mi kering semakin tinggi. Hal ini dikarenakan gliserol monostearat memiliki kemampuan untuk menyerap air dengan adanya gugus hidrofilik yang dimilikinya, sedangkan meningkatnya tepung terigu akan memperbesar jumlah protein sehingga jumlah gugus hidrofilik akan lebih besar pula. Semakin tinggi gugus hidrofilik, maka peyerapan air akan semakin meningkat. Hal ini sesuai dengan peryataan Mudjisihono dkk.(1993), produk yang ditambah gliserol monostearat memiliki kapasitas penyerapan air lebih tinggi dibandingkan produk tanpa gliserol monostearat. Hal ini disebabkan gliserol monostearat dapat menghalangi penggabungan molekul-molekul pati dengan protein sehingga gugus $\mathrm{OH}$ bebas pada gliserol monostearat yang berikatan jumlahnya relatif banyak. 
Tabel 1. Nilai rata-rata Kadar Air Mi Kering perlakuan substitusi tepung gembili dan penambahan GMS

\begin{tabular}{|c|c|c|}
\hline \multicolumn{2}{|l|}{ Perlakuan } & \multirow[t]{2}{*}{ Rata-rata Kadar Air (\%) } \\
\hline Proporsi Terigu : Gembili (\%) & GMS (\%) & \\
\hline \multirow[t]{3}{*}{$100: 0$} & 1 & $9,10 \pm 0,014^{j}$ \\
\hline & 2 & $9,26 \pm 0,042^{\mathrm{k}}$ \\
\hline & 3 & $9,42 \pm 0,042^{1}$ \\
\hline \multirow[t]{3}{*}{$85: 15$} & 1 & $8,60 \pm 0,028^{g}$ \\
\hline & 2 & $8,73 \pm 0,028^{\mathrm{h}}$ \\
\hline & 3 & $8,85 \pm 0,050^{\mathrm{i}}$ \\
\hline \multirow[t]{3}{*}{$70: 30$} & 1 & $8,01 \pm 0,042^{\mathrm{d}}$ \\
\hline & 2 & $8,21 \pm 0,028^{e}$ \\
\hline & 3 & $8,35 \pm 0,050^{\mathrm{f}}$ \\
\hline \multirow{3}{*}{$55: 45$} & 1 & $7,29 \pm 0,021^{\mathrm{a}}$ \\
\hline & 2 & $7,51 \pm 0,028^{b}$ \\
\hline & 3 & $7,81 \pm 0,035^{\mathrm{c}}$ \\
\hline
\end{tabular}

*) angka yang didampingi huruf yang berbeda menunjukkan perbedaan yang nyata $(\mathrm{p}<0,05)$

\section{Kadar Protein}

Hasil analisa ragam menunjukkan bahwa perlakuan substitusi tepung gembili tidak terdapat interaksi, tetapi terdapat perbedaan yang nyata $(\mathrm{p}<0,05)$ terhadap kadar protein Mi kering yang dihasilkan, sedangkan pada penambahan gliserol mono stearat tidak terdapat perbedaan yang nyata $(\mathrm{p}>0,05)$ terhadap kadar Mi kering yang dihasilkan.

Nilai rata - rata kadar protein Mi kering dengan perlakuan proporsi tepung terigu : tepung gembili adalah $0,782 \%-2,450 \%$ dan dapat dilihat pada Tabel 2 .

Tabel 2. Nilai rata-rata Kadar Protein Mi Kering perlakuan proporsi tepung terigu : tepung gembili.

\begin{tabular}{cc}
\hline Proporsi T. Terigu : T. Gembili (\%) & Rata-rata Kadar Protein (\%) \\
\hline $100: 0$ & $9,88 \pm 0,012^{\mathrm{d}}$ \\
$85: 15$ & $7,51 \pm 0,066^{\mathrm{c}}$ \\
$70: 30$ & $6,50 \pm 0,023^{\mathrm{b}}$ \\
$55: 45$ & $5,08 \pm 0,024^{\mathrm{a}}$ \\
\hline
\end{tabular}

*) angka yang didampingi huruf yang berbeda menunjukkan perbedaan yang nyata $(\mathrm{p}<0,05)$

Pada Tabel 2 menunjukkan bahwa semakin rendah proporsi tepung terigu dan semakin tinggi proporsi tepung gembili maka kadar protein pada Mi kering semakin menurun, hal ini dikarenakan kadar protein pada tepung terigu lebih tinggi dibanding dengan kadar protein pada tepung gembili. Meningkatnya proporsi terigu akan meningkatkan kadar protein $\mathrm{Mi}$ kering. Menurut Ricana (2004), kadar protein pada tepung gembili adalah $6,11 \%$ dan menurut Hujaedi (2016), kadar protein pada tepung terigu adalah $12,67 \%$. Hal ini sesuai dengan pendapat Purnomo (1994), penurunan kadar protein terjadi dengan adanya penambahan tepung selain tepung terigu yang dapat mengakibatkan kandungan gluten dan protein dalam adonan menjadi rendah, sehingga mempengaruhi penurunan kadar protein produk yang dihasilkan.

Nilai rata-rata kadar protein Mi kering dengan penambahan gliserol monostearat adalah $1,546 \%$ - $1,779 \%$ dan dapat dilihat pada Tabel 3. 
Tabel 3. Nilai rata-rata Kadar Protein Mi Kering perlakuan penambahan gliserol mono stearat.

\begin{tabular}{cc}
\hline $\begin{array}{c}\text { Penambahan Gliserol } \\
\text { Monostearate } \\
(\%)\end{array}$ & Rata-rata Kadar Protein $(\%)$ \\
\hline 1 & $7,26 \pm 1,867^{\mathrm{a}}$ \\
2 & $7,24 \pm 1,875^{\mathrm{a}}$ \\
3 & $7,23 \pm 1,876^{\mathrm{a}}$ \\
\hline
\end{tabular}

*) angka yang didampingi huruf yang berbeda menunjukkan perbedaan yang nyata $(\mathrm{p}<0,05)$

Pada Tabel 3. dapat dilihat bahwa hasil statistik menunjukkan tidak pengaruh nyata terhadap kadar protein $\mathrm{Mi}$ kering yang dihasilkan. Hal ini dikarenakan gliserol mono stearat tersusun bukan oleh fraksi protein sehingga semakin tinggi penambahan GMS (gliserol mono stearat) tidak berpengaruh pada kadar protein. Hal ini sesuai dengan pendapat Mudjisihono dkk (1993), variasi penambahan gliserol monostearat tidak menyebabkan perbedaan kadar protein pada produk yang dihasilkan karena gliserol monostearat sebagian besar tersusun bukan oleh fraksi protein, tetapi gliserol monostearat tersusun dari asam stearat (Hidayat, 2006).

\section{Kadar Pati}

Berdasarkan analisa ragam menunjukkan bahwa perlakuan proporsi tepung terigu : tepung gembili dan penambahan gliserol monostearat terdapat interaksi yang nyata dan masing-masing factok berpengaruh nyata $(\mathrm{p}<0,05)$ terhadap kadar pati Mi kering yang dihasilkan. Nilai rata-rata kadar pati Mi kering tiap kombinasi perlakuan dapat dilihat pada Tabel 4.

Tabel 4. Kadar pati Mi kering dari perlakuan substitusi tepung gembili dan penambahan gliserol monostearat.

\begin{tabular}{ccc}
\hline Perlakuan & & Rata-rata Kadar Pati (\%) \\
\cline { 1 - 2 } Proporsi Terigu : Gembili (\%) & GMS (\%) & \\
\hline $\mathbf{1 0 0}: \mathbf{0}$ & 1 & $51,98 \pm 0,170^{\mathrm{c}}$ \\
& 2 & $51,32 \pm 0,184^{\mathrm{b}}$ \\
$\mathbf{8 5}: \mathbf{1 5}$ & 3 & $50,42 \pm 0,290^{\mathrm{a}}$ \\
& 1 & $55,89 \pm 0,050^{\mathrm{f}}$ \\
& 2 & $55,06 \pm 0,106^{\mathrm{e}}$ \\
$\mathbf{7 0}: \mathbf{3 0}$ & 3 & $54,39 \pm 0,219^{\mathrm{d}}$ \\
& 1 & $60,49 \pm 0,375^{\mathrm{i}}$ \\
& 2 & $59,12 \pm 0,283^{\mathrm{h}}$ \\
$\mathbf{5 5}: \mathbf{4 5}$ & 3 & $57,59 \pm 0,537^{\mathrm{g}}$ \\
& 1 & $63,27 \pm 0,219^{\mathrm{j}}$ \\
& 2 & $62,69 \pm 0,184^{\mathrm{k}}$ \\
& 3 & $62,04 \pm 0,071^{1}$ \\
\hline
\end{tabular}

*) angka yang didampingi huruf yang berbeda menunjukkan perbedaan yang nyata $(\mathrm{p}<0,05)$

Pada Tabel 4. Terlihat bahwa substitusi tepung gembili $45 \%$ dan penambahan gliserol monostearat $1 \%$ memiliki nilai rata-rata kadar pati paling tinggi yaitu $63,27 \%$, dan pada perlakuan substitusi tepung gembili 15 dan penambahan gliserol monostearat 3\% memiliki nilai rata-rata kadar pati yang paling rendah yaitu 54,39\%. Hasil tersebut menunjukan bahwa dengan semakin tinggi proporsi tepung gembili dan semakin rendah penambahan glierol monostearat maka kadar pati Mi kering semakin meningkat. Hal ini dikarenakan kadar pati tepung gembili lebih tinggi dibandingkan pada tepung terigu, dan gliserol monostearat dapat mencegah hilangnya amilosa yang merupakan bagian 
dari pati selama proses pemanasan. Hal ini sesuai dengan pernyataan Hui (1996), rantai gliserol monostearat bereaksi dengan molekul-molekul amilosa secara heliks. Akibat reaksi tersebut membentuk ikatan antar molekul-molekul amilosa dapat tertahan selama proses pengolahan (Mudjisihono dkk., 1993).

\section{Karakteristik Fisik Mi Kering (daya rehidrasi, elastisitas dan cooking loss)}

Hasil analisa ragam menunjukkan bahwa perlakuan substitusi tepung gembili dan penambahan gliserol monostearat tidak terdapat interaksi yang nyata terhadap daya rehidrasi, elastisitas dan cooking loss $\mathrm{Mi}$ kering, tetapi masing-masing perlakuan berpengaruh nyata $(\mathrm{p}<0,05)$ terhadap karakteristik fisik Mi kering.

Nilai rata-rata daya rehidrasi, elastisitas dan cooking loss $\mathrm{Mi}$ kering dengan perlakuan substitusi tepung gembili dapat dilihat pada Tabel 5.

Tabel 5. Nilai rata-rata Daya Rehidrasi, Elastisitas dan Cooking loss Mi Kering perlakuan substitusi tepung gembili.

\begin{tabular}{cccc}
\hline $\begin{array}{c}\text { Proporsi Tepung Terigu : } \\
\text { tepung Gembili (\%) }\end{array}$ & Daya Rehidrasi (\%) & Elastisitas $(\%)$ & Cooking loss $(\%)^{\mathrm{a}}$ \\
\hline $100: 0$ & $39,07 \pm 1,218^{\mathrm{a}}$ & $37,33 \pm 0,643^{\mathrm{d}}$ & $5,74 \pm 0,325^{\mathrm{a}}$ \\
$85: 15$ & $44,37 \pm 2,889^{\mathrm{b}}$ & $25,27 \pm 0,408^{\mathrm{c}}$ & $7,71 \pm 0,212^{\mathrm{b}}$ \\
$70: 30$ & $50,56 \pm 2,382^{\mathrm{c}}$ & $19,75 \pm 0,538^{\mathrm{b}}$ & $9,03 \pm 0,181^{\mathrm{c}}$ \\
$55: 45$ & $55,73 \pm 1,130^{\mathrm{d}}$ & $16,07 \pm 0,536^{\mathrm{a}}$ & $10,41 \pm 0,336^{\mathrm{d}}$ \\
\hline
\end{tabular}

*) angka yang didampingi huruf yang berbeda menunjukkan perbedaan yang nyata $(\mathrm{p}<0,05)$.

Pada Tabel 5. menunjukkan bahwa semakin rendah proporsi tepung terigu dan semakin tinggi proporsi tepung gembili maka daya rehidrasi Mi kering semakin meningkat, hal ini dikarenakan gembili memiliki kadar pati yang lebih tinggi dibanding tepung terigu. Hal ini sesuai dengan penelitian Rosida dan Rizky (2012), semakin tinggi penambahan tepung gembili akan menaikan kadar pati Mi kering yang dihasilkan karena pati bersifat dapat mengikat air. Hal ini menyebabkan daya rehidrasi Mi kering semakin meningkat.

Semakin rendah proporsi tepung terigu dan semakin tinggi proporsi tepung gembili, maka daya elastisitas Mi kering akan semakin rendah. Hal ini dikarenakan semakin berkurangnya tepung terigu pada pembuatan Mi kering maka kandungan gluten pada adonan Mi akan semakin berkurang, semakin rendahnya gluten pada Mi maka elastisitas pada Mi akan menurun. Hal ini sesuai dengan penelitian Rosida dan Rizky (2012), semakin berkurangnya tepung terigu pada pembuatan Mi kering maka secara langsung dapat mengurangi kandungan gluten yang terdapat pada tepung terigu sehingga akan menurunkan daya elastisitas pada Mi kering.

Semakin rendah proporsi tepung terigu dan semakin tinggi proporsi tepung gembili, maka cooking loss $\mathrm{Mi}$ kering semakin meningkat. Hal ini dikarenakan semakin rendahnya proporsi tepung terigu sehingga kemampuan gluten untuk mengikat bahan semakin menurun. Menurut Widowati (2009), gluten memiliki kemampuan untuk membentuk jaringan tiga dimensi yang menghambat keluarnya isi granula pada bahan.

Nilai rata-rata daya rehidrasi, elastisitas dan cooking loss $\mathrm{Mi}$ kering dengan penambahan gliserol monostearat adalah dan dapat dilihat pada Tabel 6.

Tabel 6. Nilai rata-rata Daya Rehidrasi, Elastisitas dan Cooking loss Mi Kering perlakuan penambahan gliserol monostearat.

\begin{tabular}{cccc}
\hline $\begin{array}{c}\text { Gliserol Monostearat } \\
(\%)\end{array}$ & Daya Rehidrasi (\%) & Elastisitas $(\%)$ & Cooking loss $(\%)$ \\
\hline 1 & $49,27 \pm 6,521^{\mathrm{a}}$ & $24,01 \pm 8,545^{\mathrm{a}}$ & $7,93 \pm 1,831^{\mathrm{a}}$ \\
2 & $47,27 \pm 7,126^{\mathrm{ab}}$ & $24,58 \pm 8,606^{\mathrm{b}}$ & $8,24 \pm 1,878^{\mathrm{b}}$ \\
3 & $45,74 \pm 6,692^{\mathrm{b}}$ & $25,19 \pm 8,641^{\mathrm{c}}$ & $8,49 \pm 1,827^{\mathrm{c}}$ \\
\hline
\end{tabular}

*) angka yang didampingi huruf yang berbeda menunjukkan perbedaan yang nyata $(\mathrm{p}<0,05)$ 
Pada Tabel 6. dapat dilihat bahwa hasil statistik menunjukan bahwa GMS berpengaruh nyata terhadap daya rehidrasi, elastisitas dan cooking loss pada Mi yang dihasilkan. Penambahan gliserol monostearat terjadinya penurunan daya rehidrasi, hal ini dikarenakan kemampuan gliserol monostearat membentuk kompleks (tidak larut air) dengan amilosa yang dapat menghalangi masuknya air kembali sehingga daya rehidrasi Mi menurun. Hal ini menyebabkan lapisan kompleks tidak larut kemungkinan terbentuk dipermukaan granula pati dan menghambat masuknya air kedalam granula pati (Richardson, et al.,2003).

Semakin tinggi penambahan GMS dapat meningkatkan elastisitas Mi kering yang dihasilkan. Hal ini dikarenakan, penambahan gliserol monostearat menyebabkan tekstur yang kompak dan kenyal pada produk yang dihasilkan. Menurut Kuswardani dkk (2008), semakin tinggi konsentrasi gliserol monostearat yang ditambahkan maka lapisan film yang terbentuk semakin kokoh dan tekstur yang dihasilkan juga semakin kokoh. Hal ini menjadikan penambahan gliserol monostearat meningkatkan daya renggang atau elastisitas pada produk yang dihasilkan. buatan yang tersusun dari asam stearat sebagai Gliserol monostearat merupakan emulsifier

gugus non polar dan mempunyai gugus hidroksil dari gliserol sebagai gugus polar. Gugus polar akan berinteraksi dengan fraksi amilosa membentuk ikatan kompleks dan matriks sehingga dapat membantu kerja gluten, sedangkan gugus non polar juga berinteraksi dengan amilosa yaitu pada pemanasan pati lebih lanjut mengakibatkan pelarutan.

Semakin tinggi penambahan GMS dapat meningkatkan cooking loss Mi yang dihasilkan. Hal ini dikarenakan kemampuan gliserol monostearat (GMS) membentuk kompleks dengan amilosa, sehingga mencegah pelepasan amilosa selama proses gelatinisasi, hal ini menyebabkan peningkatan cooking loss ketika Mi kering dimasak (Charutigon, et al, 2008).

\section{Uji Sensoris (Warna, Aroma dan Tekstur) Mi}

Warna merupakan parameter fisik yang penting. Perlakuan subatitusi tepung gembili dan penambahan gliserol monostearat berpengaruh nyata terhadap warna, aroma dan tekstur) Mi kering yang dihasilkan. Nilai ratarata jumlah ranking warna, aroma dan tekstur Mi kering dapat dilihat pada Tabel 7.

Tabel 7. Nilai rata-rata uji sensoris warna, aroma dan tekstur Mi kering dari perlakuan substitusi tepung gembili dan penambahan gliserol monostearat

\begin{tabular}{|c|c|c|c|c|}
\hline \multicolumn{2}{|c|}{ Perlakuan } & \multicolumn{3}{|c|}{ Jumlah Ranking } \\
\hline \multirow{2}{*}{ Proporsi Terigu: Gembili (\%) } & Gliserol monostearat $(\%)$ & \multicolumn{2}{c|}{} \\
\cline { 5 - 5 } & 1 & Warna & Aroma & Tekstur \\
\hline $100: 0$ & 2 & 195,00 & 156,00 & 168,50 \\
\hline & 3 & 202,50 & 162,00 & 186,00 \\
\hline $85: 15$ & 1 & 215,50 & 176,00 & 197,50 \\
\hline & 2 & 109,50 & 122,00 & 135,00 \\
\hline & 3 & 128,50 & 127,00 & 158,00 \\
\hline $70: 30$ & 1 & 132,00 & 114,50 & 183,00 \\
\hline & 2 & 88,50 & 123,50 & 108,00 \\
\hline & 3 & 97,50 & 133,00 & 100,50 \\
\hline & 1 & 111,50 & 118,00 & 113,50 \\
\hline & 2 & 107,50 & 122,50 & 54,50 \\
\hline & 3 & 83,00 & 100,50 & 74,50 \\
\hline & 2 & 89,00 & 105,00 & 81,00 \\
\hline
\end{tabular}

Keterangan : semakin tinggi total rangking, maka semakin disukai panelis 
Tabel 7. menunjukkan tingkat kesukaan terhadap warna $\mathrm{Mi}$ kering didapatkan nilai rata-rata adalah berkisar 83,00 - 215,50 dengan warna kekuningan hingga coklat tua. Perlakuan proporsi tepung terigu:tepung gembili 100:0 dan penambahan gliserol monostearat 3\% yaitu 215,50 menghasilkan warna Mi kering dengan tingkat kesukaan tertinggi (kekuningan) dan perlakuan proporsi tepung terigu:tepung gembili 55:45 dan penambahan gliserol monostearat $2 \%$ yaitu 83,00 menghasilkan warna Mi kering dengan tingkat kesukaan terendah (coklat tua).

Mi kering yang dihasilkan berwarna coklat muda hingga coklat. Warna Mi kering tersebut berasal dari bahan baku yang digunakan yaitu tepung gembili dan tepung terigu, yang mana warna terpung gembili berwarna kecoklatan sedangkan warna bahan baku tepung terigu berwarna putih. Warna Mi kering yang disukai oleh panelis yaitu berwarna coklat muda, sedangkan warna yang tidak disukai panelis yaitu berwarna coklat tua. Peningkatan proporsi tepung gembili menyebabkan penurunan tingkat penerimaan panelis terhadap warna Mi kering. Menurut Winarno (1997), warna pada makanan dapat disebabkan oleh beberapa sumber diantaranya pigmen, pengaruh panas pada gula (karamel), reaksi antara gula dan asam amino (maillard), dan adanya pencampuran bahan lain.

Tingkat kesukaan terhadap aroma Mi kering didapatkan nilai rata-rata adalah berkisar 100,50 - 176,00. Perlakuan proporsi tepung terigu:tepung gembili 100:0 dan penambahan gliserol monostearat 3\% yaitu 176,00 menghasilkan aroma Mi kering dengan tingkat kesukaan tertinggi dan perlakuan proporsi tepung terigu:tepung gembili 55:45 dan penambahan gliserol monostearat $2 \%$ yaitu 100,50 menghasilkan aroma Mi kering dengan tingkat kesukaan terendah.

Secara umum terlihat bahwa semain tinggi penambahan tepung gembili menurunkan penerimaan aroma $\mathrm{Mi}$ kering yang dihasilkan. Hal ini menunjukkan bahwa penambahan tepung gembili dengan proporsi lebih besar akan menghasilkan aroma khas gembili sehingga mempengaruhi pada aroma Mi yang dihasilkan. Adapun variasi penambahan gliserol monostearat tidak mempengaruhi aroma Mi kering. Hal ini sesuai dengan penelitian Siregar dkk (2010), yang menjelaskan bahwa penambahan gliserol monostearat tidak mempengaruhi warna, aroma, dan rasa.

Tingkat kesukaan terhadap tekstur Mi kering didapatkan nilai rata-rata adalah berkisar 54,50-197,50. Perlakuan proporsi tepung terigu:tepung gembili 100:0 dan penambahan gliserol monostearat 3\% yaitu 197,50 menghasilkan tekstur Mi kering dengan tingkat kesukaan tertinggi dan perlakuan proporsi tepung terigu:tepung gembili 55:45 dan penambahan gliserol monostearat $1 \%$ yaitu 54,50 menghasilkan tekstur Mi kering dengan tingkat kesukaan terendah.

Peningkatan proporsi tepung gembili menyebabkan penurunan tingkat penerimaan panelis terhadap tekstur Mi kering. Hal ini karena semakin tinggi proporsi tepung gembili, maka tekstur Mi kering menjadi kurang baik dan panelis memberikan penilaian rendah. Semakin tinggi proporsi tepung gembili yang ditambahan juga akan mengurangi kandungan protein gluten sehingga Mi kering menjadi rapuh dan mudah patah.

Peningkatan tingkat kesukaan tekstur terlihat penambahan gliserol monostearat mempengaruhi tekstur Mi kering. Semakin tinggi tingkat penambahan gliserol monostearat, maka tekstur akan semakin baik. Hal ini sesuai dengan penelitian Subarna dkk (2012), bahwa penambahan GMS 1\% (dari berat tepung) ternyata mampu memperbaiki karakteristik Mi kering jagung yang telah di rehidrasi. Bahwa Mi kering jagung yang telah di rehidrasi memiliki elongasi, ketegaran, kekenyalan, dan penampakan umum yang disukai panelis.

\section{KESIMPULAN}

Mi kering tepung gembili dengan perlakuan substitusi tepung gembili $15 \%$ dan penambahan GMS(gliserol mono stearat) 3\% merupakan perlakuan terbaik dengan nilai kadar air 8,84\%, kadar protein 7,50\%, kadar pati 55,99\%, daya rehidrasi 41,93\%, elastisitas $25,69 \%$, cooking loss $7,94 \%$, dan jumlah rangking kesukaan warna 132,00, aroma 114,50 , dan tekstur 183,00. 


\section{DAFTAR PUSTAKA}

Alam, N., Saleh, M.S., Haryadi. 2007. Sifat Fisikokimia dan Sensoris Instant Starch Noodle (Isn) Pati Aren Pada Berbagai Cara Pembuatan. J. Agroland, Vol. 14 (4): 269-274.

AOAC. 2005. Official Method of Analysis of the Association of Official Analysis. Chemist. 18th ed. Maryland: AOAC International. William Harwitz (ed). United States of America.

Astawan, M. 2006. Membuat Mi dan Bihun. Penebar Swadaya, Jakarta.

Billina, A., Waluyo, S., dan Suhandi, D. 2014. Kajian Sifat Fisik Mi Basah Dengan Penambahan Rumput Laut. Jurnal Teknik Pertanian. 4(2): 109-116.

De Man, J.M. 1997. Kimia Makanan Edisi Kedua. Penerbit ITB, Bandung. Di dalam Kartikasari, E., 2000. Pembuatan Mi Basah Dengan Penambahan Tepung Ubi Jalar Kuning dan Putih Telur. Skripsi. Jurusan Teknologi Pangan. Universitas Pembangunan Nasional "Veteran" Jawa Timur. Surabaya.

Fennema, O. R. 1996. Food Chemistry, third edition. Marcel Dekker, Inc. New York.

Fu, B. X. 2008. "Asian Noodle: History, Classification, Raw Materials, and Processing", Food Res. Int., 41(9):888902

Harijono, Estiasih, T., Sunarharum, B.W. dan Rakhmita, I.S. 2010. Karakteristik Kimia Ekstrak Polisakarida Larut Air dari Umbi Gembili (Dioscorea Esculenta) yang Ditunaskan. Skripsi. Program Studi Ilmu dan Teknologi Pangan. Fakultas Teknologi Pertanian Universitas. Brawijaya. Malang.

Haryadi. 2014. Teknologi Mi, Bihun, Sohun. Yogyakarta. Gadjah Mada University Press.

Hidayat, R. 2006. Pembuatan Roti Tawar (Kajian Subsitusi Tepung Tapioka dan Penambahan Gliserol Monostearat). Jurnal Teknologi Pangan. Hal : 130 136.
Hou, G. 2010. Asian Noodle: Science, Technolog, and Processing. New Jersey: John Willey and Sons.

Hujaedi, A.W. 2016. Aplikasi Tepung bengkuang (Pachyrhizus erosus) Termodifikasi Dalam Pembuatan Roti Tawar. Skripsi. Jurusan Teknologi Pangan. Universitas Pembangunan Nasional "Veteran" Jawa Timur. Surabaya.

Husnan, S. dan Muhammad, S . 2000. Studi Kelayakan Proyek. Unit Penerbit dan Pencetak AMP YKPN. Yogyakarta.

Indah, D.P. 2011. Gembili (Dioscorea esculenta). http://fpk.unair.co.id. [Diakses pada tanggal 17 September 2016 pukul 18.30 WIB].

Kaur, L., and Singh, N. 2005. Effect of glycerol monostearate on the physicochemical, thermal, Hydrocoll.19: 839849.

Koswara, S. 2005. Teknologi Pengolahan Mi. E-bookPangan.com. Di dalam Aulia. 2016. Formulasi Produk Mi Keing Menggunakan Mocaf, Tepung terigu, Pekatan Protein Kacang Tunggak dan Tepung Porang. Skripsi. Jurusan Teknologi Pangan. Fakultas Teknik Industri, Universitas Pembangunan Nasional "Veteran" Jawa Timur. Surabaya.

Kuswardani, K., Trisnawati, Y.Ch., dan Faustine. 2008. Kajian Penggunaan Gliserol Monostearat pada Roti Tawar Non Gluten yang Terbuat dari Maizena, Tepung Beras dan Tapioka. Jurnal Teknologi Pangan dan Gizi. Vol. 7(1) : $55-65$

Mudjisihono, Munarso, J., dan Noor, Z. 1993. Pengaruh Penambahan Tepung Kacang Hijau dan Gliserol Monostearat pada Tepung Jagung Terhadap Sifat Fisik dan Organoleptik Roti Tawar. BPTP Sukamandi.

Purnomo, A.E. 1994. Pengaruh Penambahan Gliserol Monostearat Pada Pembuatan Roti Tawar dengan Subtitusi Tepung Selain Terigu. Laporan Skripsi. Fakultas Teknologi Pertanian - IPB. Bogor. 
Rahayu, W.P. 2001. Penuntun Praktikum Penilaian Organoleptik. Jurusan Teknologi Pangan dan Gizi. Fakultas Teknologi Pertanian. Institut Teknologi Bandung.

Richana, N. dan Sunarti, T.C. 2004. Karakterisasi sifat fisikokimia tepung umbi dan tepung pati dari umbi ganyong, suweg, ubi kelapa, dan gembili. Balai Besar Penelitian dan Pengembangan Pascapanen Pertanian. Fakultas Teknologi Pertanian. Institut Pertanian Bogor. Jurnal Pascapanen 1(1)2004:29-37.

Rimbawan, dan Nurbayani, R. 2013. Nilai Indeks Glikemik Produk Olahan Gembili (Discorea esculenta). Jurnal Gizi dan Pangan. 8(2): 145-150.

Risti, Y. 2013. Pengaruh Penambahan Telur Terhadap Kadar Protein, Serat, Tingkat Kekenyalan dan Penerimaan Mi Basah Bebas Gluten Berbahan Baku Tepung Komposit. Artikel Penelitian. Program Studi Ilmu Gizi, Fakultas Kedokteran Universitas Diponegoro. Hal 09.

Roberfroid, M.B. (2005). Introducing inulintype fructans". British Journal. British journal of nutrition 93: Suppl. 1,S13S15.

Rosida dan Rizky, D.W. 2012. "Mi dari tepung komposit (terigu, gembili (Dioscorea esculenta), labu kuning) dan penambahan telur". Jurnal rekapangan. 6(1) 32-37.

Royaningsih. 1987. Pembuatan Mi Basah (Boilled Noodle). Di dalam Proceding Penelitian Pasca Panen Pertanian. Bogor

Sardesai, VM. 2003. Introduction to Clinical Nutrition. Ed ke-2. USA: Marcel Dekker, Inc on: Herb Panduan Hunters.
Silva, R.F.1996. Use of inulin as a natural texture modifier. Cereal Foods World 41: 792-795

Soesarsono. 2003. Memulai dan Menggerakkan Wirausaha. Fakultas Teknologi Pertanian, Institut Pertanian Bogor.

Subarna, Muhandri, T., Nurtama, B., dan Firlieyanti, A.S. 2012. Peningkatan Mutu Mi Kering Jagung Dengan Penerapan Kondisi optimum Proses dan Penambahan Monogliserida. Jurnal Teknol dan Teknologi Pangan. 23(2):146-152

Widiatmoko, R.B dan Teti, E. 2015. Karakteristik Mi Kering Berbasis Tepung Ubi Jalar. Jurnal Pangan dan Agroindustri 3(4): 1386-1392.

Widowati, S. 2009. Tepung Aneka Umbi Sebuah Solusi Ketahanan Pangan. http:pustaka.litbang.deptan.go.id/inovas i/k109052.pdf. Diakses tanggal 28 Januari 2017

Winarno, F. G. 1997. Kimia Pangan Dan Gizi. Jakarta: PT. Gramedia Pustaka Utama. Di dalam Aulia. 2016. Formulasi Produk Mi Kering Menggunakan Mocaf, Tepung terigu, Pekatan Protein Kacang Tunggak dan Tepung Porang. Skripsi. Jurusan Teknologi Pangan. Fakultas Teknik Industri, Universitas Pembangunan Nasional "Veteran" Jawa Timur. Surabaya.

Winarti, S., Harmayani, E. dan Nurismanto, R. 2011 . "Karakteristik dan profil inulin beberapa jenis uwi (Dioscorea spp.)". AGRITECH 31:4,378-383.

Yuniar, D.P. 2010. Karakteristik Beberapa Umbi Uwi (Dioscorea spp.) dan Kajian Potensi Kadar Inulinnya. Skripsi, Fakultas Teknologi Industri Universitas Pembangunan Nasional "Veteran".Surabaya. 